\title{
Regeneration, Nutritional Values, and Antioxidants in Excised Adventitious Shoot of Radish Affected by Dark Treatment
}

\author{
Hyun-Sug Choi ${ }^{1}$, Se Ji Jang' ${ }^{2}$ Hye Ji Park², Young Beom Yun², Yong In Kuk ${ }^{2, *}$ \\ ${ }^{1}$ Department of Horticulture, Catholic University of Daegu, Gyeongsan, Gyeongsangbuk-do 712-702, Republic of Korea \\ ${ }^{2}$ Department of Development in Oriental Medicine Resources, Sunchon National University, Suncheon, Jeollanam-do, Republic of Korea \\ *Corresponding author: yikuk@sunchon.ac.kr
}

Received May 28, 2015; Revised June 10, 2015; Accepted June 24, 2015

\begin{abstract}
The study was to evaluate regeneration, mineral nutrients, and antioxidative activities of adventitious shoot in tuberous root radish (Raphanus sativus L.) grown under light and dark conditions in a controlled growth chamber. Small pieces of top of root radish, including adventitious shoots, were detached from mother radish roots $\left(1^{\text {st }}\right.$ cut $)$ and grown for 22 days $\left(22 \mathrm{DAC}_{1}\right)$, which then re-cut $\left(2^{\text {nd }}\right.$ cut $)$ and re-grown for 23 days $\left(23 \mathrm{DAC}_{2}\right)$. Fresh weight was heavier on plants grown under the dark condition (6.2 g) at $22 \mathrm{DAC}_{1}$ compared to the light condition (5.2 g) but was not significantly different between the treatment conditions at $23 \mathrm{DAC}_{2}$. Shoot length was significantly extended by the dark condition during the experimental period. Leaf concentrations of $\mathrm{Ca}, \mathrm{Mg}, \mathrm{Na}$, and $\mathrm{Mn}$ were significantly increased by the light condition, with high leaf concentrations of $\mathrm{Fe}, \mathrm{Zn}$, and $\mathrm{Cu}$ observed on the dark condition. Proline of total amino acids was highly increased by the light condition (126.8 $\mathrm{mg} \mathrm{g}^{-1}$ ) compared to dark condition $\left(16.3 \mathrm{mg} \mathrm{g}^{-1}\right)$, but other total amino acid concentrations were varied between the treatment conditions. Fructose and sucrose were increased by dark and light conditions, respectively. Dark condition reduced scavenging activity (9.7\%), total phenolic $\left(12.2 \mathrm{mg} \mathrm{g}^{-1}\right)$ and flavonoid compounds $\left(0.05 \mathrm{mg} \mathrm{g}^{-1}\right)$ compared to the light condition (scavenging activity; $49.3 \%$, total phenolic $43.8 \mathrm{mg} \mathrm{g}^{-1}$ and flavonoid compounds; $0.21 \mathrm{mg} \mathrm{g}^{-1}$ ) at $22 \mathrm{DAC}_{1}$, which was also observed at $23 \mathrm{DAC}_{2}$. Excised adventitious shoot of radish grown under the dark condition could be useful propagation technique for convenient consumption at all times and the physicochemical values to some degree.
\end{abstract}

Keywords: antioxidant, dark, nutrient, radish, regeneration

Cite This Article: Hyun-Sug Choi, Se Ji Jang, Hye Ji Park, Young Beom Yun, and Yong In Kuk, "Regeneration, Nutritional Values, and Antioxidants in Excised Adventitious Shoot of Radish Affected by Dark Treatment.” Journal of Food and Nutrition Research, vol. 3, no. 6 (2015): 365-370. doi: 10.12691/jfnr-3-6-2.

\section{Introduction}

Conventional farming system, using rapidly solubilized chemical materials, such as chemical fertilizer and pesticide, had been extensively employed in an agricultural land since World War II to improve yield efficiency and save labor cost and efforts [1]. Conventional farming systems caused high potential of an environmental pollution and destructed soil ecosystems, experiencing difficulty of food safety for fresh vegetables and fruits [1]. Organic farming systems have applied natural products and recycling resources of plants and soil existing in the region, contributing to making solid food safety or promoting ecological diversity. Classical farming systems in South Korea were overall based on the natural resources that were readily accessible in a farmland, which may help to expand the base of current organic farming technologies.

Traditional farming technology, such as cultivation of minimum tillage and cultivation of crop softening, has descended up to this day with an old agriculture book [2].
However, the traditional technology was rarely practiced in time and space and needed to evaluate their effects on the crop ecophysiological responses. Light quantity and quality were one of the key concerns to improve crop productivity, and shading decreased overall production of plant biomass through the decline of net photosynthesis [3]. On the other hand, softening cultivation employed dark conditions to induce etiolated vegetables in an original agriculture, which was verified through improved total amino acids in Allium tuberosum and reduced fiber contents in adventitious shoots of Allium victorialis compared to those grown under light conditions [4,5].

Although radish (Raphanus sativus L.) and Allium tuberosum used to be easily grown under a softening cultivation indoors [4], responses of radish grown under a dark condition was rarely reviewed scientifically, in particular for the nutritional values and antioxidants of the adventitious shoots produced in repeated cut. Radish is an important ingredient made for a Kimchi, which was the main side dish for Korean people, and the remnant of radish after making Kimchi could be replanted to regenerate adventitious shoots [4]. The objective of this study was to compare regrowth, mineral nutrients, and 
antioxidative activities of radish root grown under light and dark conditions.

\section{Materials and Methods}

\subsection{Plant Source and Sampling}

'Youngdong' radish seeds were sown in the nursery media $\left(\mathrm{NH}_{4}^{+}, 300 \mathrm{mg} \mathrm{l}^{-1}\right.$; $\mathrm{NO}_{3}^{-}, 200 \mathrm{mg} \mathrm{l}^{-1}$; EC, $0.7 \mathrm{dS} \mathrm{m}^{-1}$; CEC, $20 \mathrm{cmol}^{+} \mathrm{l}^{-1}$; Tobaeki; Sunghwa Co., Boseong, South Korea) on 28 August 2011 in an Agricultural Experimental Station, Sunchon National University, Suncheon, South Korea $\left(35^{\circ} \mathrm{N} ; 127^{\circ} \mathrm{E}\right)$. The radishes were harvested on 20 February 2012 for use of the experimental materials. Approximately 5-cm of adventitious shoots, including upper parts of the radish roots (approximately five $\mathrm{cm}$ long) were detached from the seedling tuberous roots $\left(1^{\text {st }}\right.$ cut), which then transplanted in a media $(40 \times 60$ $\mathrm{cm}, \mathrm{NH}_{4}^{+}, 300 \mathrm{mg} \mathrm{l}^{-1}$; $\mathrm{NO}_{3}^{-}, 200 \mathrm{mg} \mathrm{l}^{-1}$; EC, $0.7 \mathrm{dS} \mathrm{m}{ }^{-1}$; CEC, $20 \mathrm{cmol} \mathrm{l}^{-1}$; Tobaeki; Sunghwa Co., Boseong, South Korea $)$ in the square pot $(40 \times 60 \mathrm{~cm})$. The excised plant materials were grown for 22 days under dark and light conditions at $15^{\circ} \mathrm{C}$ in a growth chamber (HB-303DH, Hanbaek Co., Bucheon, South Korea). Dark and light conditions were applied as a treatment to observe physiological responses of the plants. Length of new adventitious shoot emerging from the detached radish roots was measured at $7,9,11,14,17,19$, and 22 days after $1^{\text {st }}$ cut $\left(\mathrm{DAC}_{1}\right)$. The extended shoots were re-cut $\left(2^{\text {nd }}\right.$ cut; $\mathrm{DAC}_{2}$ ) from $3-\mathrm{cm}$ above the top of radish root and measured their fresh weight $(\mathrm{FW})$. Re-extension of the shoot was observed at $6,8,10,13,15,17,21$, and 23 $\mathrm{DAC}_{2}$, and $\mathrm{FW}$ of the regeneration was measured at 23 $\mathrm{DAC}_{2}$.

Leaves were sampled at $22 \mathrm{DAC}_{1}$ for analysis of mineral nutrients, with collecting leaves+shoots for amino acids and soluble carbohydrates. Leaves+shoots were also harvested at $22 \mathrm{DAC}_{1}$ and $23 \mathrm{DAC}_{2}$ to measure antioxidative activities.

\subsection{Nutrient Analyses}

Leaves were put in a dry oven at $65^{\circ} \mathrm{C}$ for three days and ground using a leaf grinder to analysis mineral nutrient concentrations according to a wet digestion method [6]. Two g of the ground samples were digested with $10 \mathrm{ml}$ of nitric acid $(20 \%, \mathrm{v} / \mathrm{v})$, slowly raising the temperature on a heat plate until the digestion solution was white transparent in a color. The digestion solution was messed up $100 \mathrm{ml}$ by distilled water and allowed to pass through a Whatman No. 6 filter paper, which were then measured by an inductively coupled plasma atomic emission spectrometer (ICP; Optima 3300 DV ICP; PerkinElmer Co., Waltham, USA).

\subsection{Total Amino Acid, Free Amino Acid, and Soluble Carbohydrate Analyses}

Two g of the dried plant samples was put in the heatresisting vial, digested with $15 \mathrm{ml}$ of $6 \mathrm{~N} \mathrm{HCl}$ in a dry oven at $110^{\circ} \mathrm{C}$ for $24 \mathrm{~h}$, centrifuged at $15,000 \mathrm{rpm}$ for 30 min, and cooled down in a room temperature to measure total amino acids [7]. The digestion solution was concentrated in a water bath at $50^{\circ} \mathrm{C}$ to evaporate hydrochloric acid and water, which was made-up to $10 \mathrm{ml}$ with sodium citrate buffer solution up to a $\mathrm{pH} 2.2$ and allowed to pass through using a $0.22 \mu \mathrm{m}$ membrane filter. The filtrate was analyzed by a S433 amino acid analyzer (Sykam Co., Eresing, Germany).

Ten $\mathrm{g}$ of the dried plant samples was homogenized using an Ace Homogenizer (Nissei Co., Tokyo, Japan) to extract free sugar and filtrated by $0.45 \mu \mathrm{m}$ membrane filter to measure free amino acids [7]. The $10 \mathrm{ml}$ of filtrate was added with $25 \mathrm{mg}$ sulfosalicylic acid at $4^{\circ} \mathrm{C}$ for $4 \mathrm{~h}$ and centrifuged at 15,000 rpm for $30 \mathrm{~min}$, and the supernatant was filtrated by $0.22 \mu \mathrm{m}$ membrane filter. The filtrate was analyzed by a S433 amino acid analyzer (Sykam Co., Eresing, Germany).

Soluble carbohydrate concentrations, fructose, glucose, and sucrose, in plants were analyzed according to the method of Wilson et al. [8]. The $5 \mathrm{~g}$ of dried plant samples was added with $50 \mathrm{ml}$ of distilled water and shacked at $30^{\circ} \mathrm{C}$ for $30 \mathrm{~min}$ in a water bath, which was centrifuged at $15,000 \mathrm{rpm}$ for $30 \mathrm{~min}$ and filtrated with $0.45 \mu \mathrm{m}$ membrane filter. The $20 \mu \mathrm{l}$ of the filtrate was used to analyze the soluble carbohydrate concentrations using high-performance liquid chromatographic (HPLC, Spectra-Physics P4000, Fremont, USA).

\subsection{Scavenging Activity, Flavonoid, and Phenol Contents}

Scavenging activity, flavonoid, and phenolic contents were analyzed with $0.5 \mathrm{~g}$ of the dried plant samples, which was digested in $10 \mathrm{ml}$ of $99.9 \%$ ethanol in the mortar, ground in a grinder, and centrifuged at 5,000 rpm for 10 min. The $100 \mu \mathrm{l}$ of supernatant, $500 \mu \mathrm{l}$ of $0.1 \mathrm{M}$ acetate buffer solution ( $\mathrm{pH} 5.5), 250 \mu \mathrm{l}$ of $0.5 \mathrm{mM}$ DPPH (2,2diphenyl-1-picrylhydarzyl), and $400 \mu \mathrm{l}$ of ethanol were mixed together for $30 \mathrm{~min}$ at room temperature. The mixed solution was determined colorimetrically using UV spectrophotometer at $517 \mathrm{~nm}$ (UV-1601; Shimadzu Co., Kyoto, Japan) to measure the scavenging activity.

The plant samples were extracted by methanol (100\%) to determine total phenolic concentration. The $1 \mathrm{ml}$ of extract was added with $3 \mathrm{ml}$ distilled water and $1 \mathrm{ml}$ Folin-Dennis' reagent, and then shacked for $5 \mathrm{~min}$. The mixed solution was left for $1 \mathrm{~h}$ at room temperature and colorimetrically measured using a UV spectrophotometer at $640 \mathrm{~nm}$ (UV-1601; Shimadzu Co., Kyoto, Japan).

For measuring total flavonoid concentration, plant samples were digested by a methanol (100\%), and the 0.5 $\mathrm{ml}$ of extract was mixed together with $1.5 \mathrm{ml}$ of ethanol (95\%), $10 \%$ of $\mathrm{AlCl}_{3}, 1 \mathrm{M}$ of potassium acetate, and 2.8 $\mathrm{ml}$ of distilled water. The mixed solution was then left for $40 \mathrm{~min}$ at room temperature and colorimetrically measured using UV spectrophotometer at $415 \mathrm{~nm}$ (UV1601; Shimadzu Co., Kyoto, Japan).

\subsection{Statistical Analysis}

The study was arranged in a completely randomized design with thirty and three radish replications of each treatment for growth and chemical compound analyses, respectively. Means were separated using Duncan's New Multiple Range Test at $P \leq 0.05$. Data were also shown as means \pm standard deviations (SD). 


\section{Results and Discussion}

New shoots emerging from the adventitious shoots of the radish root were extended at a length under the dark condition, which was nearly two times longer than those of the light condition at $22 \mathrm{DAC}_{1}$ (Figure 1) as observed in Allium tuberosum [4] and Allium victorialis [5]. Regrowth followed by $2^{\text {nd }}$ cut was significantly different between the light regimes, and shoots were significantly extended by the dark condition (Figure 1). Shading regime promoted levels of gibberellin (GA) biosynthesis through mediation by indole-3-acetic acid (IAA) [9]. Plants altered their morphology through shoot extension and leaf expansion as a shading avoidance. Dark condition may have induced the internal free IAA [10], presumably resulting in the extended shoot but not the FW due to the produced thinner shoots under the dark condition.
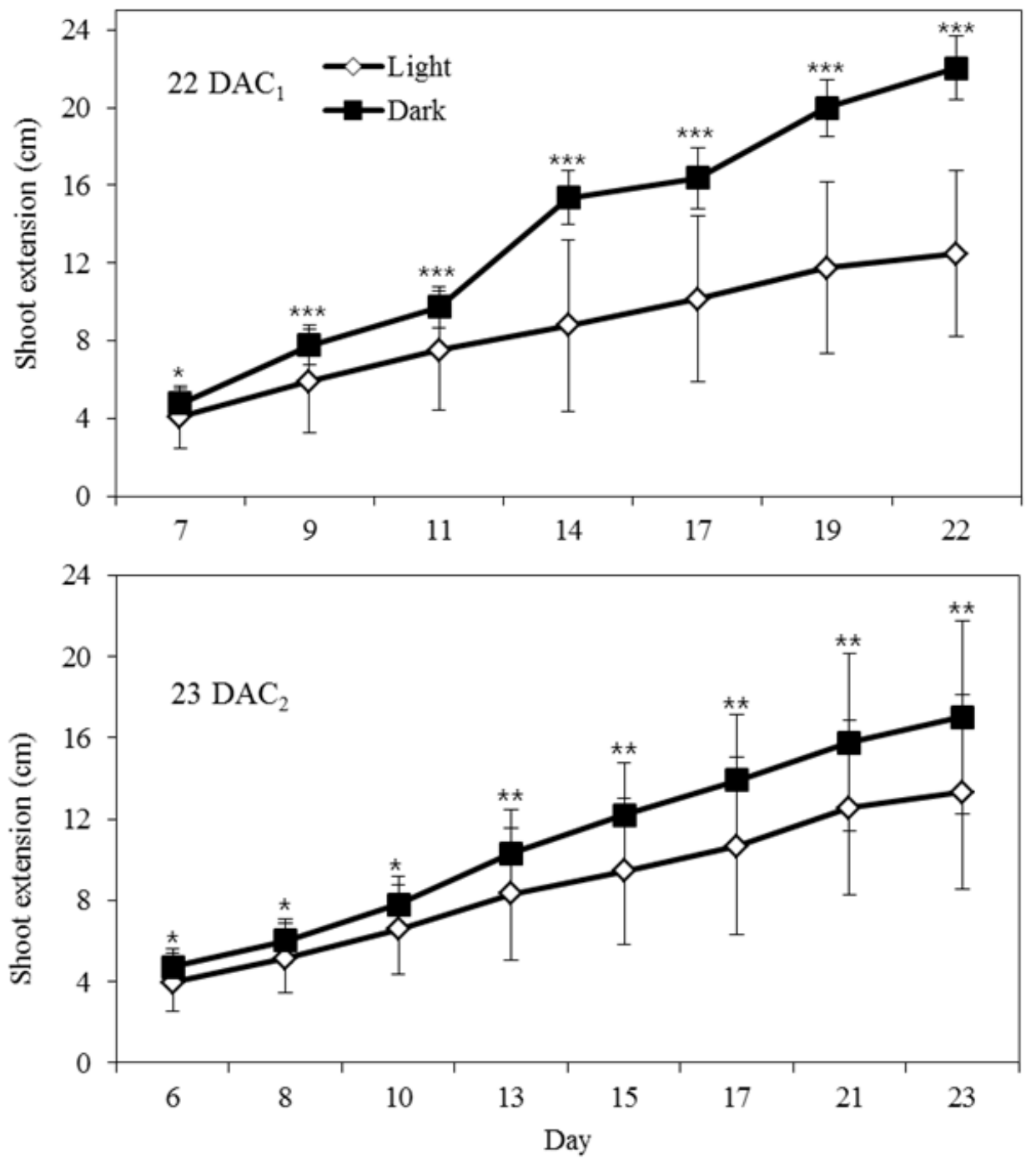

Figure 1. Shoot extension in radish grown under light and dark conditions at 22 days after $1^{\text {st }}$ cut $(22$ DAC $)$ and at 23 days after $2^{\text {nd }}$ cut $\left(23\right.$ DAC C $_{2}$. Data are means $\pm \mathrm{SD}(\mathrm{n}=30)$. *, $* * * * *$ adjacent to each datum point at each sampling date indicate significantly different means at $P \leq 0.05, P \leq 0.01$, and $P \leq 0.001$, respectively as determined by Duncan's MRT

Survival of the adventitious shoots was $100 \%$ under both light and dark conditions at $22 \mathrm{DAC}_{1}$ and $23 \mathrm{DAC}_{2}$ (Table 1). Tuberous radish roots, containing adventitious shoots, would have reserved mineral nutrients to some degree that satisfied for shoot extension during the experimental period although decline of light intensity reduced net photosynthesis, decreasing plant growth and the productivity [3]. Plant FW was $1.0 \mathrm{~g}$ higher in dark compared to the light condition at $22 \mathrm{DAC}_{1}$, mostly causing from the enlarged shoots, but was similar to the both treatment conditions at $23 \mathrm{DAC}_{2}$.

Table 1. Survival and fresh weight (FW) of adventitious shoots in radish grown under light and dark conditions at 22 days after $1^{\text {st }}$ cut (22 $\left.\mathrm{DAC}_{1}\right)$ and 23 days after $2^{\text {nd }}$ cut $\left(23 \mathrm{DAC}_{2}\right.$ )

\begin{tabular}{l|c|c|c|c}
\hline Treatment & \multicolumn{2}{|c|}{$22 \mathrm{DAC}_{1}\left(1^{\text {st }}\right.$ cut $)$} & \multicolumn{2}{c}{$23 \mathrm{DAC}_{2}\left(2^{\text {nd }}\right.$ cut $)$} \\
\hline Light & Survival (\%) & Plant FW (g) & Survival (\%) & Plant FW (g) \\
\hline Dark & $100 \pm 0$ & $5.2 \pm 1.2$ & $100 \pm 0$ & $5.1 \pm 2.5$ \\
\hline Significance & $100 \pm 0$ & $6.2 \pm 1.8$ & $100 \pm 0$ & $4.4 \pm 2.2$ \\
\hline ns & ns & ns & $\mathrm{ns}$ \\
\hline
\end{tabular}

Data are means \pm SD $(n=30)$.

*Significantly different means at $P \leq 0.05$ as determined by Duncan's MRT. ns, not significantly different. 
Concentrations of mineral nutrients, such as $\mathrm{Ca}$, Mg, $\mathrm{Na}$, and $\mathrm{Mn}$, were higher in leaves grown under the light condition than those of dark condition at $22 \mathrm{DAC}_{1}$ (Table 2), presumably due to the dilution effect causing from the less FW produced under the light condition. Another assumption was decline of Ca levels in the dark-treated plants may have reduced membrane integrity, contributing to lower concentration of $\mathrm{Mg}$ and to degradation of function of chloroplasts, eventually reducing concentration of $\mathrm{Na}$ or $\mathrm{Mn}$ [11]. High concentrations of mineral nutrients were also observed on Allium tuberosum plants grown under a light condition [4]. However, the dark condition increased concentrations of $\mathrm{Fe}, \mathrm{Zn}$, and $\mathrm{Cu}$ in leaves as the elevated concentrations of the cation, such as $\mathrm{Ca}, \mathrm{Mg}, \mathrm{Na}$, and $\mathrm{Mn}$ may have partially inhibited uptake of those mineral nutrients into the shoots [12].

Table 2. Mineral nutrient concentrations of leaves of adventitious shoots in radish grown under light and dark conditions at 22 days after $1^{\text {st }}$ cut

\begin{tabular}{|c|c|c|c|c|c|c|c|}
\hline \multirow{2}{*}{ Treatment } & \multicolumn{7}{|c|}{ Mineral nutrients $\left(\mathrm{g} \mathrm{kg}^{-1} \mathrm{DW}\right)$} \\
\hline & $\mathrm{Ca}$ & $\mathrm{Mg}$ & $\mathrm{Na}$ & $\mathrm{Fe}$ & $\mathrm{Mn}$ & $\mathrm{Zn}$ & $\mathrm{Cu}$ \\
\hline Light & $68 \pm 4$ & $19 \pm 1$ & $34 \pm 0$ & $0.29 \pm 0.03$ & $0.33 \pm 0.03$ & $0.16 \pm 0.01$ & $0.30 \pm 0.11$ \\
\hline Dark & $50 \pm 1$ & $13 \pm 0$ & $18 \pm 0$ & $0.36 \pm 0.03$ & $0.27 \pm 0.02$ & $0.18 \pm 0.00$ & $0.51 \pm 0.16$ \\
\hline Significance & $* * *$ & $* * *$ & $* * *$ & $* * *$ & $* * *$ & $*$ & $* * *$ \\
\hline
\end{tabular}

Data are means \pm SD $(n=9)$.

*, ***Significantly different means at $P \leq 0.05$ and $P \leq 0.001$, respectively as determined by Duncan's MRT.

Proline was accumulated in leaves responded to the unfavorable environment [13]. However, proline was the largely component in total amino acids in plants grown under the light condition (126.8 mg $\left.100 \mathrm{~g}^{-1} \mathrm{DW}\right)$ compared to the dark-treated plants (16.3 mg $100 \mathrm{~g}^{-1} \mathrm{DW}$ ) as observed for Allium tuberosum [4] but was not appeared for the free amino acid (Table 3). After detaching from the radish root, the shading may have relieved rising stress levels and flow of photosynthetic rates and reduced proline accumulation, which was in

accordance with findings of tomato plants [14]. The concentrations of total amino acids were not consistently affected by the both treatment conditions, and much high concentration of glutamic acid was observed on lighttreated plants and high isoleucine in dark-treated plants. A large part of free amino acid was not significantly different on the treatment conditions, and glutamic acid, glycine, alanine, tyrosine, histidine, and cysteine were highly increased in plants grown under the light condition.

Table 3. Concentrations of total and free amino acids of adventitious shoot+leaves in radish grown under light and dark conditions at 22 days after $1^{\text {st }}$ cut

\begin{tabular}{|c|c|c|c|c|c|c|}
\hline \multirow{2}{*}{ Amino acids } & Light & Dark & Significance & Light & Dark & Significance \\
\hline & \multicolumn{3}{|c|}{ Total amino acid (mg $\left.100 \mathrm{~g}^{-1} \mathrm{DW}\right)$} & \multicolumn{3}{|c|}{ Free amino acid (mg $\left.100 \mathrm{~g}^{-1} \mathrm{DW}\right)$} \\
\hline Aspartic acid & $19.4 \pm 1.6$ & $19.2 \pm 2.1$ & ns & $0.48 \pm 0.17$ & $0.23 \pm 0.05$ & ns \\
\hline Threonine & $6.8 \pm 0.6$ & $9.1 \pm 1.0$ & $*$ & $4.55 \pm 3.39$ & $2.22 \pm 1.00$ & ns \\
\hline Serine & $8.7 \pm 0.6$ & $8.7 \pm 0.9$ & ns & $0.25 \pm 0.44$ & $0.00 \pm 0.00$ & ns \\
\hline Glutamic acid & $66.1 \pm 4.2$ & $26.7 \pm 3.0$ & $* * *$ & $0.92 \pm 0.20$ & $0.24 \pm 0.04$ & $* *$ \\
\hline Proline & $126.8 \pm 9.1$ & $16.3 \pm 2.7$ & $* * *$ & $0.91 \pm 0.91$ & $2.40 \pm 0.37$ & ns \\
\hline Glycine & $6.6 \pm 0.5$ & $10.2 \pm 1.1$ & $* *$ & $0.28 \pm 0.12$ & $0.06 \pm 0.02$ & * \\
\hline Alanine & $13.3 \pm 0.8$ & $13.3 \pm 1.5$ & ns & $1.65 \pm 0.33$ & $0.72 \pm 0.01$ & $* *$ \\
\hline Valine & $8.2 \pm 0.6$ & $10.3 \pm 1.1$ & $*$ & $0.72 \pm 0.15$ & $0.39 \pm 0.17$ & ns \\
\hline Methionine & $2.4 \pm 0.2$ & $3.6 \pm 0.4$ & $*$ & $0.06 \pm 0.04$ & $0.03 \pm 0.01$ & ns \\
\hline Isoleucine & $5.9 \pm 0.3$ & $18.4 \pm 2.1$ & $* * *$ & $0.41 \pm 0.24$ & $0.20 \pm 0.08$ & ns \\
\hline Leucine & $8.7 \pm 1.8$ & $0.0 \pm 0.0$ & $* *$ & $0.25 \pm 0.07$ & $0.25 \pm 0.06$ & ns \\
\hline Tyrosine & $2.7 \pm 0.3$ & $5.1 \pm 0.7$ & $* *$ & $0.25 \pm 0.02$ & $0.16 \pm 0.04$ & * \\
\hline Phenylalanine & $5.4 \pm 0.5$ & $10.4 \pm 1.2$ & $* *$ & $0.28 \pm 0.11$ & $0.31 \pm 0.16$ & ns \\
\hline Histidine & $12.3 \pm 0.7$ & $9.6 \pm 1.0$ & $*$ & $2.58 \pm 0.63$ & $1.07 \pm 0.02$ & $*$ \\
\hline Lysine & $9.7 \pm 0.8$ & $12.8 \pm 1.4$ & $*$ & $0.47 \pm 0.13$ & $0.27 \pm 0.05$ & ns \\
\hline Arginine & $17.2 \pm 1.1$ & $11.7 \pm 1.4$ & $* *$ & $1.41 \pm 0.66$ & $0.60 \pm 0.45$ & ns \\
\hline Cysteine & $0.0 \pm 0.0$ & $0.0 \pm 0.0$ & ns & $0.09 \pm 0.00$ & $0.03 \pm 0.00$ & $* * *$ \\
\hline Total & 320.1 & 185.4 & & 15.6 & 9.2 & \\
\hline
\end{tabular}

Data are means \pm SD $(n=3)$.

*,**, ***Significantly different means at $P \leq 0.05, P \leq 0.01$, and $P \leq 0.001$, respectively as determined by Duncan's MRT. ns, not significantly different.

Shading reduced leaf photosynthesis and inhibited accumulation of soluble carbohydrate and starch contents, resulting in a loss of soluble solids [15]. This was identified that sucrose concentration increased in the light condition but rarely detected in dark condition (Figure 2). However, fructose was approximately two times higher on the plants grown under the dark condition compared to the light condition. Carbohydrates synthesized in the leaves were translocated into other organs, mainly with sucrose or proline, and the translocation rate was considerably affected by the rate of photosynthesis [16]. Therefore,

dark condition would have reduced import of photoassimilates and reduced translocated into sucrose in plants, which may have remained more fructose type of soluble carbohydrate in the cell.

Antioxidants in plants protected free radicals attacks and prevented cell damage in biologically important cellular components [17]. The synthesis of phenolic compounds was strongly related to the antioxidant activity (DPPH) levels [18]. Light condition increased DPPH (scavenging activity), and concentration of total phenol and flavonoid at $22 \mathrm{DAC}_{1}$ and $23 \mathrm{DAC}_{2}$, except for the 
phenol at $23 \mathrm{DAC}_{2}$ (Table 4) compared to the dark condition. Increased DPPH and other phenolic compounds were also observed on Allium tuberosum [4], Aruncus diocicus [19], Youngia sonchifolia [20], Brassica oleracea
[21], and Lactuca sativa [22] grown under light conditions. Light condition could stimulate phenylalanine ammonialyase activity in the leaves and increase antioxidants as observed in the Brassica oleracea plants [21].

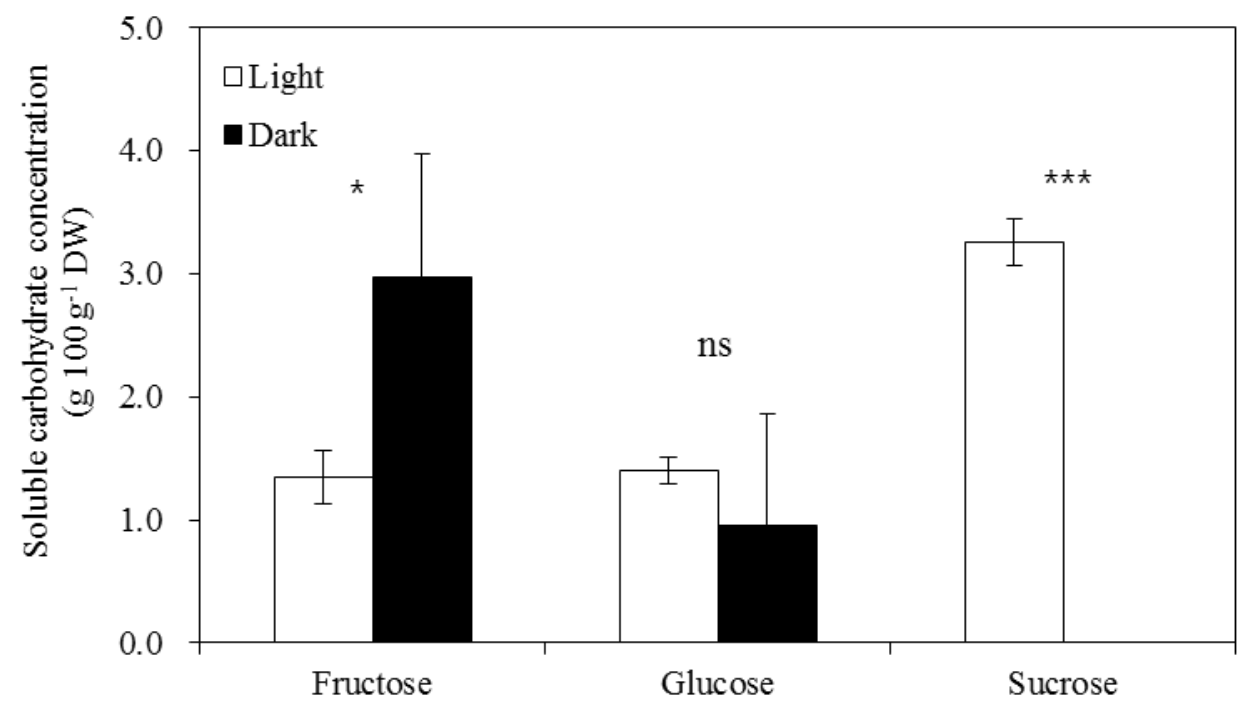

Figure 2. Soluble carbohydrate concentration in radish grown under light and dark conditions at 22 days after $1^{\text {st }}$ cut. Data are means $\pm S D(n=3) . *$, *** on each parameter indicate significantly different means at $P \leq 0.05$ and $P \leq 0.001$, respectively as determined by Duncan's MRT. ns, not significantly different

Table 4. Scavenging activity (DPPH), and total phenolic and total flavonoid concentrations of adventitious shoot+leaves in radish grown under light and dark conditions at 22 days after $1^{\text {st }}$ cut $\left(22 \mathrm{DAC}_{1}\right)$ and at 23 days after $2^{\text {nd }}$ cut $\left(23 \mathrm{DAC}_{2}\right)$

\begin{tabular}{l|c|c|c|c|c|c}
\hline \multirow{2}{*}{ Treatment } & \multicolumn{3}{|c|}{22 DAC } & \multicolumn{3}{c}{$23 \mathrm{DAC}_{2}$} \\
\cline { 2 - 8 } & $\begin{array}{c}\text { Scavenging activity } \\
(\%, \mathrm{FW})\end{array}$ & $\begin{array}{c}\text { Phenol } \\
\left(\mathrm{mg} \mathrm{g}^{-1} \mathrm{DW}\right)\end{array}$ & $\begin{array}{c}\text { Flavonoid } \\
\left(\mathrm{mg} \mathrm{g}^{-1} \mathrm{DW}\right)\end{array}$ & $\begin{array}{c}\text { Scavenging activity } \\
(\%, \mathrm{FW})\end{array}$ & $\begin{array}{c}\text { Phenol } \\
\left(\mathrm{mg} \mathrm{g}^{-1} \mathrm{DW}\right)\end{array}$ & $\begin{array}{c}\text { Flavonoid } \\
\left(\mathrm{mg} \mathrm{g}^{-1} \mathrm{DW}\right)\end{array}$ \\
\hline Light & $49.3 \pm 6.1$ & $43.8 \pm 1.8$ & $0.21 \pm 0.02$ & $0.29 \pm 0.03$ & $0.62 \pm 0.37$ & $0.47 \pm 0.07$ \\
\hline Dark & $9.7 \pm 1.8$ & $12.2 \pm 3.1$ & $0.05 \pm 0.00$ & $0.09 \pm 0.02$ & $0.53 \pm 0.04$ & $0.06 \pm 0.02$ \\
\hline Significance & $* * *$ & $* * *$ & $* *$ & $* * *$ & ns & $* * *$ \\
\hline
\end{tabular}

Data are means \pm SD $(n=3)$.

***Significantly different means at $P \leq 0.001$, respectively as determined by Duncan's MRT. ns, not significantly different.

In conclusion, dark condition significantly increased shoot length and FW of excised adventitious shoots in radish roots, compensating for the lack of photoassimilates for a while through the tuberous radish roots. Also, dark condition was resulted in maintaining high levels of some of mineral nutrients, amino acids, and fructose in dventitious shoots, which could be a useful propagation technique to be easily consumed indoors at all times. However, further research is needed to understand how plant hormones are triggered by the light regime and thereby affecting physiological responses in the excised plants.

\section{Acknowledgements}

This work was carried out with the support of "Cooperative Research Program for Agriculture Science \& Technology Development (Project No. 01083903)" Rural Development Administration, Republic of Korea.

\section{References}

[1] Lotter, D.W, “Organic agriculture,” Journal of Sustainable Agriculture, 21. 59-128. 2003.

[2] Guh, J.O. and Kuk, Y.I, "Weeding hypothesis on direct seeding rice field as applied by the old firing and water dressing method," Korean Journal of Weed Science, 31. 1-7. 2011.
[3] Poorter, H. and Nagel, O, "The role of biomass allocation in the growth response of plants to different levels of light, $\mathrm{CO}_{2}$, nutrients and water: a quantitative review," Functional Plant Biology, 27. 595-607. 2000.

[4] Yun, Y.B, Ryu, D.K., Jang, S.J., Kwon, O.D., Choi, H.S., Jung, H.I. and Kuk, Y.I, "Growth, physiochemical components, and antioxidative activities of Chinese chive (Allium tuberosum Rottler) grown under light and dark conditions," Korean Journal of International Agriculture, 24. 331-336. 2012.

[5] Choi, S.T., Lee, J.T. and Park, W.C, "Dormancy physiology, softening culture and evaluation of nutrition value in the Ulrungnative Allium victorialis var. platyphyllum," Journal of the Korean Society for Applied Biological Chemistry, 36. 495-501. 1993.

[6] Woo, S.J. and Ryoo, S.S, "Preparation methods for atomic absorption and spectrophotometry of food samples," Korean Journal of Food Science and Technology, 15. 225-231. 1983.

[7] Ohara, I. and Shujiro, A, "Comparison of protein precipitants for the determination of free amino acids in plasma," Agricultural and Biological Chemistry, 43. 1473-1478. 1979.

[8] Wilson, A.M., Work, T.M., Bushway, A.A. and Bushway, R.J, "HPLC determination of fructose, glucose, and sucrose in potatoes,” Journal of Food Science, 46. 300-301. 1981.

[9] Colebrook, E.H., Thomas, S.G., Phillips, A.L. and Hedden, P, "The role of gibberellin signaling in plant responses to abiotic stress,” Journal of Experimental Biology, 217. 67-75. 2014.

[10] Tamimi, S. and Firn, R.D, "The basipetal auxin transport system and the control of cell elongation in hypocotyls," Journal of Experimental Botany, 36. 955-962. 1985.

[11] Pill, W.G. and Lambeth, V.N, "Effects of $\mathrm{NH}_{4}$ and $\mathrm{NO}_{3}$ nutrition with and without $\mathrm{pH}$ adjustment on tomato growth, ion composition, and water relations," Journal of the American Society for Horticultural Science, 102. 78-81. 1977.

[12] Epstrin, E, "Mineral nutrition of plants: mechanisms of uptake and transport,” Annual Review of Plant Physiology, 7. 1-24. 1956. 
[13] Pérez-Alfocea, F., Estan, M.F., Caro, M. and Guerrier, G, "Osmotic adjustment in Lycopersicon esculentum and L. pennellii under $\mathrm{NaCl}$ and polyethylene glycol 6000 iso-osmotic stresses," Physiologia Plantarum, 87. 493-498. 1993.

[14] Claussen, W., Brückner, B., Krumbein, A. and Lenz, F, "Longterm response of tomato plants to changing nutrient concentration in the root environment- the role of proline as an indicator of sensory fruit quality,” Plant Science, 171. 323-331. 2006.

[15] McArtney, S.J. and Ferree, D.C, "Shading effects on dry matter partitioning, remobilization of stored reserves and early season vegetative development of grapevines in the year after treatment," Journal of the American Society for Horticultural Science, 124. 591-597. 1999.

[16] Geiger, D.R. and Batey, J.W, "Translocation of ${ }^{14} \mathrm{C}$ sucrose in sugar beet during darkness,” Plant Physiology, 42. 1743-1749. 1967.

[17] Cartea, M.E. and Velasco, P, "Glucosinolates in Brassica foods: bioavailability in food and significance for human health," Phytochemistry Reviews, 7. 213-229. 2008.
[18] Wang, S.Y., Chen, C.T. and Wang, C.Y, "The influence of light and maturity on fruit quality and flavonoid content of red raspberries," Food Chemistry, 112. 676-684. 2009.

[19] Kwon, J.W., Park, J.H., Kwon, K.S., Kim, D.S., Jeong, J.B., Lee, H.K., Sim, Y.E., Kim, M.S., Young, J.Y., Chung, G.Y. and Jeong, H.J, "Effect of shading practices on the chemical compounds and antioxidant in Aruncus diocicus," Korean Journal of Plant Resources, 19. 1-7. 2006.

[20] Chon, S.U, "Shading effect on plant growth and physiological activity of Youngia sonchifolia growth in plastic house," Korean Journal Weed Science, 30. 215-224. 2010.

[21] Jin, P., Yao, D., Xu, F., Wang, H. and Zheng, Y, "Effect of light on quality and bioactive compounds in postharvest broccoli florets," Food Chemistry, 172. 705-709. 2015.

[22] Samuoliene, G., Sirtautas, R., Brazaityte, A. and Duchovskis, P, "LED lighting and seasonality effects antioxidant properties of baby leaf lettuce,” Food Chemistry, 134. 1494-1499. 2012. 